D. Ó Foighil · P. M. Gaffney · A. E. Wilbur · T. J. Hilbish

\title{
Mitochondrial cytochrome oxidase I gene sequences support an Asian origin for the Portuguese oyster Crassostrea angulata
}

Received: 15 April 1997 / Accepted: 12 February 1998

\begin{abstract}
The Portuguese oyster Crassostrea angulata (Lamarck, 1819) was long assumed to be native to the northeastern Atlantic, however, a number of lines of evidence now indicate that it is a close relative, or identical, to the Asian Pacific oyster C. gigas (Thunberg, 1793). Three hypotheses have been proposed to explain how this strikingly disjunct geographic distribution may have come about: ancient vicariance events, recent anthropogenic introduction to Asia and recent anthropogenic introduction to Europe. We have performed a molecular phylogenetic analysis of $C$. angulata based on mitochondrial DNA sequence data for a 579-nucleotide fragment of cytochrome oxidase I. Our results show that Portuguese oyster haplotypes cluster robustly within a clade of Asian congeners and are closely related, but not identical, to C. gigas from Japan. The mitochondrial data are the first to show that Portuguese oysters are genetically distinct from geographically representative samples of Japanese Pacific oysters. Our phylogenetic analyses are consistent with a recent introduction of C. angulata to Europe either from a non-Japanese Asian source population or from a subsequently displaced Japanese source population. Genetic characterization of Pacific oysters throughout their Asian range is necessary to fully reveal the phylogenetic relationships among Portuguese and Pacific oysters.
\end{abstract}

Communicated by J.P. Grassle, New Brunswick

D. Ó Foighil $(\bowtie)$

Museum of Zoology and Department of Biology, University of Michigan,

Ann Arbor, Michigan 48109-1079, USA

P.M. Gaffney · A.E. Wilbur

College of Marine Studies, University of Delaware,

Lewes, Delaware 19958, USA

T.J. Hilbish

Delle W. Baruch Institute, University of South Carolina, Columbia, South Carolina 29208, USA

\section{Introduction}

It has become abundantly clear over the past decade that human-mediated transoceanic exchange on a massive scale is presently ongoing among global nearshore faunas (Carlton 1985, 1987, 1989; Hallegraeff and Bloch 1992; Carlton and Geller 1993; Paine 1993; Cohen et al. 1995; Geller 1996). The present-day distribution of some geographically extensive marine taxa may have been achieved by undocumented anthropogenic transfer, rather than by incremental spontaneous dispersal events over evolutionarily significant time frames (Carlton 1989). The scope of this process may be seriously underestimated where human-mediated introductions predate biological surveys (Carlton 1989) and where the species involved are inconspicuous or are difficult to distinguish using morphological characters (Geller 1996).

The Portuguese oyster Crassostrea angulata (Lamarck, 1819) represents a putative case of undocumented introduction which may have occurred soon after the genesis of global shipping routes (Ranson 1960; Menzel 1974; Edwards 1976; Buroker et al. 1979). This species was long assumed to be native to the northeastern Atlantic, however, Ranson (1948, 1960, 1967), on the basis of larval shell morphology, claimed that the Portuguese oyster is a geographically isolated population of the Asian Pacific oyster C. gigas. Subsequent investigators have compiled an impressive list of similarities between these two geographically distant taxa that support Ranson's proposal. These congeners are indistinguishable in terms of enzyme polymorphisms (Mathers et al. 1974; Buroker et al. 1979; Mattiucci and Villani 1983) and karyotype (Thiriot-Quiévreux 1984). Reciprocal crosses exhibit normal or near-normal rates of fertilization and development (Imai and Sakai 1961; Menzel 1974), and Walne and Helm (1979) noted normal growth and viability in $F_{1}$ and $F_{2}$ hybrids. Reports of successful hybridization in bivalves must be viewed with some caution, however, as hatchery contamination is commonplace (Gaffney and Allen 1993). 
There is also evidence supporting the distinctiveness of Portuguese and Pacific oysters. Hèral and DeslousPaoli (1991), on the basis of physiological reproductive characteristics, have contended that Pacific and Portuguese oysters are two separate species. Some ultrastructural studies of spermatogenesis in Crassostrea gigas (Brandiff et al. 1978; Komaru et al. 1994), and in C. angulata (Gutíerrez et al. 1978), have reported a difference in sperm acrosomal morphology, although this is not supported by Sousa and Oliveira (1994). Minor differences have also been reported for adductor muscle protein patterns (Moré et al. 1971) and for antigen profiles (Numachi 1962), but it is not clear if these distinctions are genetic in origin.

Available evidence strongly suggests that Portuguese and Pacific oysters are at least sister taxa, if not the same species. Three hypotheses have been proposed to explain how this strikingly disjunct geographic distribution may have come about. Stenzel (1971) and Lawrence (1995) argue that Pacific and Portuguese oysters are both descended from a Miocene fossil taxon, Crassostrea gryphoides, prevalent in the Eurasian Tethyan Seaway. They claim that Portuguese and Japanese oyster populations have been separated since before closure of the Seaway and that their demonstrated similarities reflect the conservative nature of their evolution rather than recent common ancestry. The other two hypotheses both assume that undocumented human-mediated introduction events have occurred, but they differ in the polarity of the proposed transfer events. Menzel (1974) argued that the ancestral stock was originally restricted to the Atlantic and was introduced to Japan during the sixteenth or seventeenth centuries by Portuguese traders. The majority view, however, is that $C$. angulata are descendants of Pacific oysters first brought to Europe by traders (Ranson 1960; Edwards 1976; Buroker et al. 1979) and that prehistoric oyster mounds in Japan demonstrate its antiquity there (Korringa 1976). More recently, the application of molecular phylogenetic methods has clearly established the Asian affinities of the Pacific oyster (Banks et al. 1993; Littlewood 1994; Ó Foighil et al. 1995).

We present here a phylogenetic analysis of Crassostrea angulata based on mitochondrial DNA sequence data. Our aim was to test the putative identity of $C$. angulata as a historically recent isolate of Japanese $C$. gigas by incorporating samples from the four historically recognized geographic races (Hokkaido, Miyagi, Hiroshima and Kyushu) of the Pacific oyster in Japan (Imai and Sakai 1961; Ahmed 1975; Quayle 1988). Our results show that the Portuguese oyster clusters within a clade of Asian congeners and is closely related, but not identical, to present day C. gigas from Japan. The ancestral Asian population that gave rise to $C$. angulata may have been displaced within Japan, or may be located in another part of Asia, most likely Taiwan (Boudry et al. 1998; J-H Cheng, Tungkang, Taiwan, personal communication).

\section{Materials and methods}

Ethanol-fixed samples of the Portuguese oyster, and of three Asian congeners, were fowarded by colleagues from wild populations and from hatchery broodstocks. Crassostrea angulata (Lamarck, 1819) were obtained from natural Sado estuary populations, in the south of Portugal, in August 1994. Samples of C. gigas (Thunberg, 1793) from each of the four historic stocks of this species in Japan were procured, two from wild populations (Hokkaido, Kyushu) and two from research hatchery broodstock (Hiroshima, Miyagi). Hokkaido C. gigas were sampled in June 1994 from the rocky intertidal at Kakijima, Atsukeshi on the southeast coast of Hokkaido. Kyushu C. gigas specimens were collected in the summer of 1992 from a wild population in Fukiage-cho, a fishing village on the west coast of Kyushu remote from oyster aquacultural locations. Hiroshima C. gigas broodstock, were obtained from the Haskin Shellfish Research in New Jersey. They were $F_{2}$ descendants of wild spat collected in Hiroshima Bay in 1988 and transferred to the Haskin Laboratory in 1990 (S. K. Allen, personal communication). Miyagi C. gigas broodstock, originally from Washington State, were also obtained from the Haskin Laboratory as were samples of $C$. ariakensis (Fujita, 1913). The C. sikamea (Amemiya, 1928) samples were progeny of commercial stock maintained in Tomales Bay (California) and in Yaquina Bay (Oregon) and confirmed as C. sikamea using diagnostic PCR/RFLP characterization of nuclear ITS1 ribosomal gene fragments (Gaffney and Wilbur, unpublished). Tissue samples from two outgroup oyster taxa were sampled from wild populations: Crassostrea virginica (Gmelin, 1791) in Delaware Bay in October 1996; and the flat oyster Ostrea chilensis (Philippi, 1845) from the shallow sublittoral at Moturekareka Island, Hauraki Gulf, New Zealand in November 1995.

DNA templates for thermal cycle amplification were prepared from mantle tissues of individual oysters as detailed by $O$ Foighil et al. (1995). A 659-nucleotide (nt) portion of oyster cytochrome oxidase I (COI) was amplified for five specimens each of the ingroup samples of Crassostrea angulata and of the Asian congeners (total of 20 individuals from the four Japanese C. gigas samples) and for one specimen each of the two outgroup taxa using the Folmer et al. (1994) primer set (5'-GGTCAACAAATCATAAAGATATTGG-3'; 5'-TAAACTTCAGGGTGACCAAAAAATCA$\left.3^{\prime}\right)$. A negative control (no template) was included in each run of 35 cycles of amplification ( 1 min $94{ }^{\circ} \mathrm{C}$ denaturing, $30 \mathrm{~s} 45{ }^{\circ} \mathrm{C}$ annealing, $1 \mathrm{~min} 72{ }^{\circ} \mathrm{C}$ extension). Double-stranded products were isolated on $1 \%$ agarose gels, excised under long-wavelength UV light $(312 \mathrm{~nm}$ ), and extracted using a GeneClean (Bio 101) NaI/ glass powder kit. For most samples, both strands of the amplified fragments were directly cycle-sequenced using the original amplification primers and electrophoresed on ABI-automated DNA sequencers at either the University of Delaware or the University of Michigan. The Hokkaido C. gigas samples and the Ostrea chilensis specimen were manually sequenced at the University of South Carolina. Due to the shorter reads generated for the manual sequences, and to the excision from analysis of $35 \mathrm{nt}$ of the $3^{\prime}$ end of

Fig. 1 Crassostrea spp., Ostrea chilensis. Alignment of nine oyster COI gene fragment genotypes (579 nucleotides) obtained in the present study with that of a homologous 588-nucleotide portion of the chiton Katherina tunicata COI [positions 67-654 of the chiton mitochondrial genome (Boore and Brown 1994)]. GIGAS, ANGUL, SIKAMEA, ARIAKEN, VIRGIN and CHILENS, respectively, indicate genotypes encountered in Crassostrea gigas, $C$. angulata, $C$. sikamea, $C$. ariakensis, $C$. virginica and Ostrea chilensis samples. Dots indicate nucleotide identity to the first sequence presented, C. gigas, and inferred changes relative to C. gigas are shown. Dashes indicate inferred nucleotide insertions/deletions relative to the chiton (KATHERIN). The number of individuals encountered per haplotype for each population sample is indicated in parentheses at the end of each sequence 
the fragment to remove a small number of ambiguous positions, our final data set consisted of 579 homologous nucleotides of COI for all of the study taxa.

Translations to inferred amino acid sequences were performed using the Drosophila yakuba mitochondrial genetic code (Clary and Wolstenholme 1985). Once aligned, sequences were analyzed using a maximum parsimony (PAUP 3.1) approach (Swofford 1993) with Ostrea chilensis designated as an outgroup. Branch support levels were estimated using Bremer support values (Bremer 1995), calculated using Treerot (Sorenson 1996), and also by bootstrapping.

\section{Results}

Figure 1 shows the genotypic variation encountered among the study taxa. A total of nine haplotypes were detected among the 37 oyster specimens sequenced for 579 homologous nucleotide positions of COI. Four of these haplotypes occurred in the Portuguese Crassostrea angulata sample. Samples of Asian congeners exhibited
GIGAS ANGUL1 ANGUL2 ANGUL 3 ANGUL 4 SIKAMEA ARIAKEN VIRGIN CHILENS KATHERIN

GIGAS

ANGUL1

ANGUL2

ANGUL 3

ANGUL 4

SIKAMEA

ARIAKEN

VIRGIN

CHILENS

KATHERIN

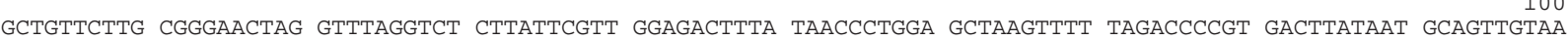

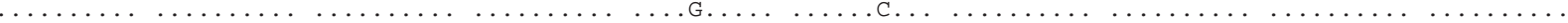

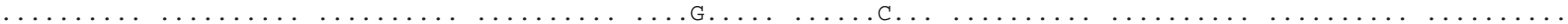

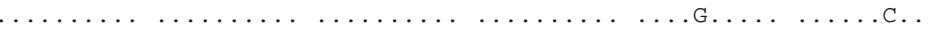

200

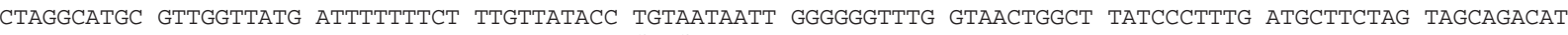

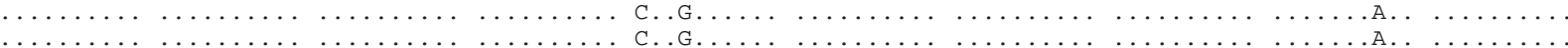

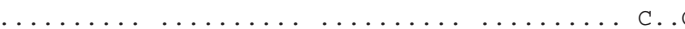
(1) . .

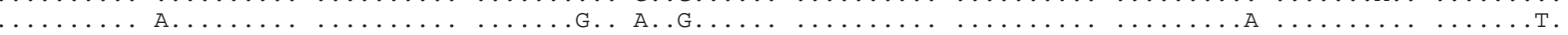

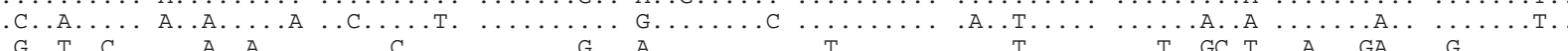

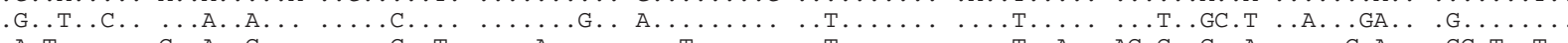

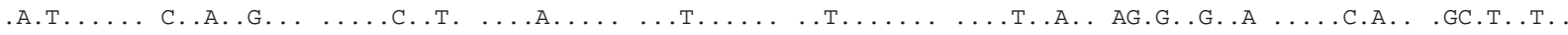

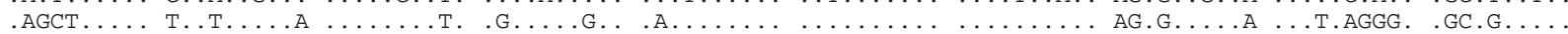

GIGAS

ANGUL1

ANGUL2

ANGUL 3

ANGUL4

SIKAMEA

ARIAKEN

VIRGIN

CHILENS

KATHERIN

\section{GIGAS \\ ANGUL1 \\ ANGUL2 \\ ANGUL 3 \\ ANGUL4 \\ SIKAMEA \\ ARIAKEN \\ VIRGIN \\ CHILENS \\ KATHERIN}

GIGAS

ANGUL1

ANGUL2

ANGUL 3

ANGUL 4

SIKAMEA

ARIAKEN

VIRGIN

CHILENS

KATHERIN

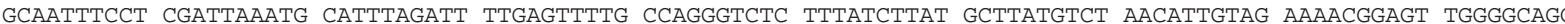

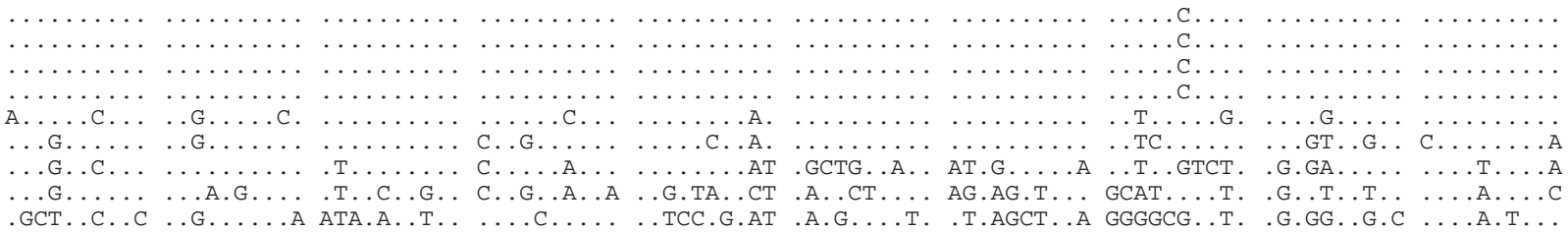

400

400

TGAACAATTT ACCCTCCTTT ATCAACTTAC TCTTATCAT- --GgAgTTTG TATAGACCTT GCAATtCTAA GCCTTCACCT TGCTGGTATT AgCTCTATtT

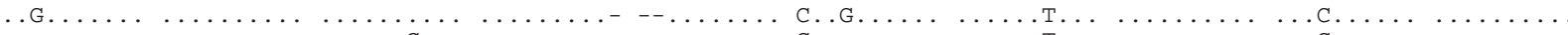

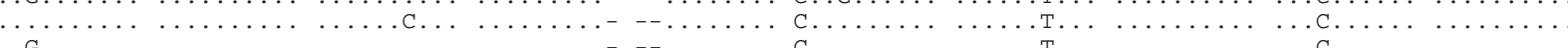

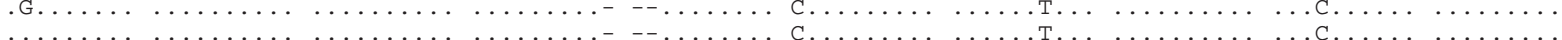

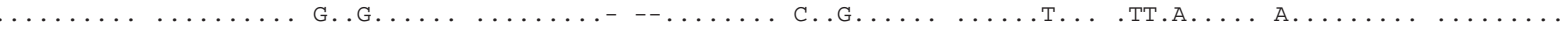

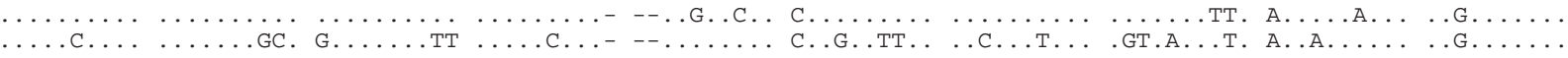

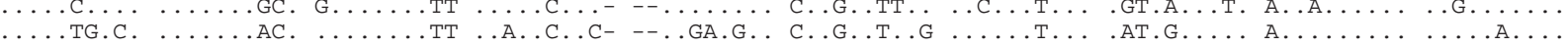
....TG.G. .T..... GG.GGGGA.T GTGGGG..G CT..T.GA.C.G.T..T.A.T..T.TT CTT.A.TT. A...AG.A TCG..... .

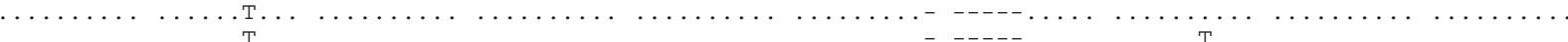

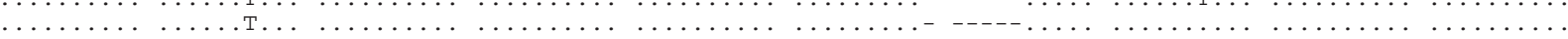

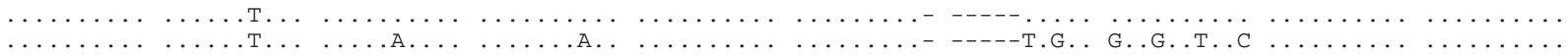

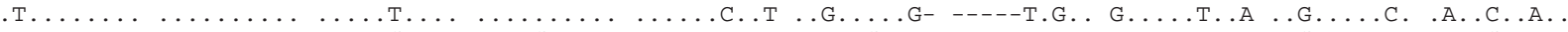

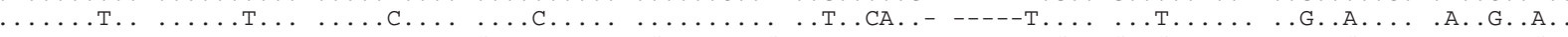

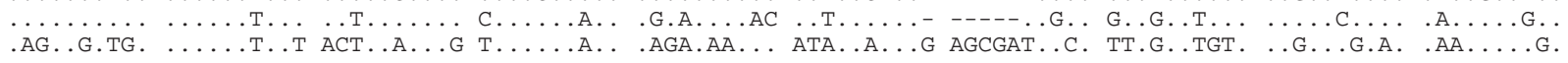

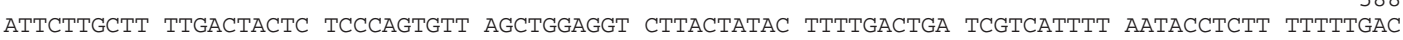


single species-specific genotypes, including all 20 specimens of the Pacific oyster $C$. gigas obtained from Hokkaido, Miyagi, Hiroshima and Kyushu. Including the outgroup taxa, 217 positions are variable in the oyster COI data set $(37,17,163$, respectively, for 1 st, 2nd and 3rd codon positions) and 87 of these are informative under conditions of parsimony. No insertion/ deletion events were detected, and Table 1 presents pairwise genetic distances among the nine genotypes. Note that the smallest genetic distances among the oyster taxa are between Pacific and Portuguese oysters.

Two most parsimonious phylogenetic trees (337 steps, $\mathrm{CI}=0.8605$; $\mathrm{RI}=0.6328$ ) were repeatedly obtained by exhaustive PAUP analyses of the oyster COI data set. They differed in one minor detail, the relative placement of two of the four Crassostrea angulata haplotypes (ANGUL2, ANGUL4) in the terminal tips of the trees. A strict consensus tree is shown in Fig. 2, and essentially the same topology was also produced by maximum-likelihood analysis. Note that the $C$. angulata genotypes are nested in a robust clade containing the Asian congeners $C$. gigas, $C$. sikamea and $C$. ariakensis and that Pacific and Portuguese oysters form a wellsupported sub-clade. C. angulata and C. gigas are clearly sister taxa, but the characterized haplotypes in these two oysters differ in their COI gene fragment sequences by a minimum of 12 substitutions. Eleven of these steps are due to inferred synonymous transitions and one results from an inferred non-synonymous transversion (position 188, Fig. 1) in which a glutamine is substituted for a leucine. We also sequenced a 444-nt fragment of the mt $16 \mathrm{~S}$ large ribosomal subunit gene for our samples of these two oyster taxa, and they differed by three additional transitions (data not shown). It is likely that $\mathrm{Pa}-$ cific and Portuguese oysters contain fixed substitutions in many of their mitochondrial genes.

\section{Discussion}

The mitochondrial COI sequence data yield intriguing new insights into the phylogenetic relationships of $\mathrm{Pa}-$ cific and Portuguese oysters. On one level, the molecular results are congruent with data on larval morphology (Ranson 1948, 1960, 1967), allozymes (Mathers et al. 1974; Buroker et al. 1979; Mattiucci and Villani 1983) and mating experiments (Imai and Sakai 1961; Menzel 1974), which indicate close phylogenetic ties between

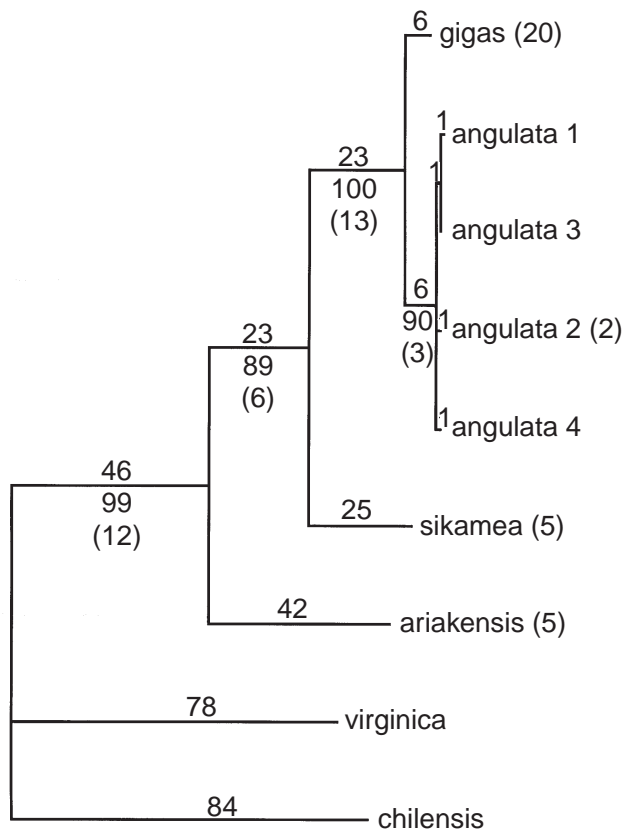

Fig. 2 Crassostrea spp., Ostrea chilensis. Strict consensus of the two most parsimonious trees (337 steps) obtained by an exhaustive search for optimal trees (PAUP) using the nine characterized oyster genotypes of a 579-nucleotide COI mitochondrial gene fragment (see Fig. 1). O. chilensis (chilensis) was employed as an outgroup. The two most parsimonious trees differed only in relative positioning of two of the four terminal $C$. angulata (angulata 2, angulata 4) haplotypes. Respective numbers of steps are indicated above each branch, and the bootstrap values (500 branch and bound iterations) and Bremer support values (in parentheses) supporting each node are presented below the branches. In parentheses after haplotype labels, numbers of individuals sequenced if $>1$

these two taxa. At the same time, the mitochondrial data, together with the complementary results of Boudry et al. (1998), are the first to demonstrate clear genetic distinctions between Crassostrea angulata and Japanese populations of $C$. gigas. These results underline the superior resolution of mitochondrial molecular characters in distinguishing closely related oyster lineages (Reeb and Avise 1990). Assessment of their systematic significance will require genetic characterization of $C$. gigas throughout its natural range in Asia.

Our molecular phylogenetic results have relevance to the three competing hypotheses proposed to explain the disjunct geographic distributions of Pacific and Portuguese oysters. The vicariance hypothesis (Stenzel 1971;
Table 1 Crassostrea spp., Ostrea chilensis. Pairwise number of sequence differences for the study oyster taxa COI gene fragments (579 nucleotides). Below diagonal all changes; above diagonal mean distances

\begin{tabular}{|c|c|c|c|c|c|c|c|c|c|}
\hline & 1 & 2 & 3 & 4 & 5 & 6 & 7 & 8 & 9 \\
\hline 1 C. gigas & & 0.024 & 0.024 & 0.022 & 0.021 & 0.093 & 0.145 & 0.214 & 0.237 \\
\hline 2 C. angulatal & 14 & & 0.007 & 0.002 & 0.003 & 0.092 & 0.154 & 0.211 & 0.242 \\
\hline 3 C. angulata 2 & 14 & 4 & & 0.005 & 0.003 & 0.092 & 0.150 & 0.214 & 0.242 \\
\hline 4 C. angulata 3 & 13 & 1 & 3 & & 0.002 & 0.093 & 0.152 & 0.212 & 0.244 \\
\hline 5 C. angulata 4 & 12 & 2 & 2 & 1 & & 0.092 & 0.150 & 0.211 & 0.242 \\
\hline 6 C. sikamea & 54 & 53 & 53 & 54 & 53 & & 0.150 & 0.225 & 0.240 \\
\hline 7 C. ariakensis & 84 & 89 & 87 & 88 & 87 & 87 & & 0.235 & 0.254 \\
\hline $8 C$. virginica & 124 & 122 & 124 & 123 & 122 & 130 & 136 & & 0.266 \\
\hline $9 O$ O. chilensis & 137 & 140 & 140 & 141 & 140 & 139 & 147 & 154 & \\
\hline
\end{tabular}


Lawrence 1995) assumes that the last common ancestor of these taxa dates from some unknown period prior to final closure of the Eurasian Tethyan Seaway in the Messinian period (late Miocene) approximately 7 million years ago (Robba 1987; Por 1989). The most compelling evidence against this hypothesis is the absence of C. angulata from the European Pliocene and Quaternary fossil record (Ranson 1948, 1960; Edwards 1976). Our molecular data may also undermine the vicariance hypothesis by indicating that closure of the Eurasian Tethyan Seaway may significantly predate the last common ancestor of Pacific and Portuguese oysters. The most detailed estimates for fossil-calibrated molluscan mtDNA divergence rates are provided by Collins et al. (1996) for a protein coding gene and by Reid et al. (1996) for a ribosomal gene. Both studies utilized marine gastropod taxa, however, they obtained remarkably distinct estimates of molecular divergence rates for these two very different genes. The Collins et al. (1996) rate (2\% per million years per lineage for Nucella species cytochrome $b$ third-codon transitional differences) is more relevant to the oyster study because it is based on largely synonymous substitutions in a protein-coding gene. Ten transitions (all synonymous) were detected in our pairwise comparisons of 190 third-codon positions for C. angulata and C. gigas COI. Application of the Nucella spp. rate to the oyster data is complicated by pronounced phylogenetic and life-history differences between the snails and the oysters, and undoubtedly yields a very crude estimate of the ages of the oyster lineages. For instance, the Nucella spp. rate may significantly overestimate oyster divergence times because there are indications of an unusually high rate of mutation, attributed to the large number of germline cell divisions per generation, in the mitochondrial genomes of cupped oysters (Beckenbach 1994). Although it may well be a significant overestimate, our observed value of $5.26 \%$ produces an estimated divergence date of 1 to 2 million years ago for the Portuguese and Pacific oyster sequences, long after closure of the Tethyan Seaway.

Our phylogenetic analyses firmly place both Portuguese and Pacific oysters within an Asian Crassostrea clade and are consistent with previous molecular characterization of $C$. gigas and its Asian congeners (Banks et al. 1993, 1994; Littlewood 1994; Ó Foighil et al. 1995). These results establish the Asian affinities of both Portuguese and Pacific oysters; they are incompatible with Menzel's (1974) hypothesis for a European origin for these taxa but are most consistent with the remaining hypothesis of undocumented recent human introduction of C. angulata to Europe (Ranson 1960; Edwards 1976; Buroker et al. 1979). A prediction of the latter hypothesis is that Portuguese oysters should share haplotypes in common with Asian source populations because insufficient time $(<500$ years) has elapsed for significant levels of new mutations to arise in the recently separated populations. The clear mitochondrial genetic divergence of Portuguese and Pacific oysters does not therefore allow us to identify a source population within Japan for
C. angulata. The observed genetic distinction between the two closely related oyster taxa may reflect: (1) inadequate sampling of genotypic diversity, (2) a founder effect in the establishment of $C$. angulata populations, (3) a non-Japanese Asian source population, and/or (4) changes in the genetic structure of Japanese oyster populations subsequent to establishment of Portuguese oysters in Europe.

Mitochondrial restriction fragment length polymorphism (RFLP) surveys of natural cupped oyster populations reveal that one or two common haplotypes typically dominate such populations in association with a large number of rare haplotypes (Reeb and Avise 1990; Beckenbach 1994; Boom et al. 1994). Our small sample sizes therefore underestimate the amount of genetic diversity in the study populations, but we have probably sampled the predominant haplotype(s). This is especially clear for the Crassostrea gigas samples from the four Japanese stocks $(n=20)$, which, remarkably, all had identical genotypes. In contrast, considerable mitochondrial diversity has been detected in RFLP population genetic studies of transplanted Miyagi stock populations in Canada (Boom et al. 1994). Some of this difference may be methodological in origin, as the RFLP approach used by Boom et al. (1994) sampled the entire mitochondrial genome, including areas that may be experiencing higher mutation rates than the $\mathrm{COI}$ fragment we characterized. Data from a contemporaneous population genetic study (Boudry et al. 1998) utilizing RFLP analyses of homologous COI mitochondrial gene fragments, however, strongly indicate that our results are a valid reflection of genetic differences among Portuguese oysters and Japanese stocks of Pacific oysters.

Another possibility is that the observed genetic divergence of Pacific and Portuguese oysters resulted from a founder effect, whereby a very small number of transplanted Japanese Crassostrea gigas, possessing rare haplotypes, established the European population. Cladistic analysis of mitochondrial RFLP variation in Pacific oysters (Boom et al. 1994) and in Gulf of Mexico and Atlantic Coast populations of American oysters (Reeb and Avise 1990) reveals that the great majority of haplotypes in these populations differ by one restriction site loss/gain from a small number of common haplotypes (Beckenbach 1994). Beckenbach (1994) proposed that this pattern reflects the interaction of a small effective population size (due to variable reproductive success of individual females) and a high rate of mitochondrial mutation in oysters. Common haplotypes occupy central positions in the cladograms, separated by single steps from the majority of the rare haplotypes which occupy terminal positions (Beckenbach 1994). The phylogenetic placement of Portuguese oyster haplotypes relative to those of Japanese Pacific oysters are not consistent with this pattern and indicate that the observed genetic divergence did not result from a founder effect. All $C$. angulata haplotypes are separated by 12 steps from Japanese $C$. gigas and constitute a distinct clade. The Portuguese/Pacific oyster mitochon- 
drial comparison does, however, resemble the pronounced mitochondrial break in $C$. virginica Gulf of Mexico/Atlantic Coast populations (Reeb and Avise 1990) both in its phylogenetic tree topology (Beckenbach 1994) and in its genetic divergence levels [11 substitutions for $C$. virginica homologous $\mathrm{COI}$ gene fragments (Gaffney, unpublished)]. It is likely that the putative Asian source population for $C$. angulata was genetically differentiated from the Japanese populations of C. gigas we have sampled and that this factor, rather than a founder effect, is responsible for our results.

The simplest and most plausible interpretation of our data is that the putative Asian source population for the Portuguese oyster exists outside of Japan and will be encountered when the Pacific oyster is genetically characterized throughout its natural range. Contemporaneous mitochondrial genetic characterization of Taiwanese samples, using RFLP analyses of COI fragments (Boudry et al. 1998) and sequencing of $16 \mathrm{~S}$ gene fragments (J-H Cheng, Tungkang, Taiwan, personal communication), strongly indicate that Taiwanese stocks represent plausible source populations. Boudry et al. (1998) have found that the predominant haplotypes from Taiwanese and from Crassostrea angulata samples share Mse I (5'TTAA-3') and Taq I (5'-TCGA-3') restriction sites which differentiate them from Japanese Pacific oysters and are consistent with our observed substitutions at positions 367 and 585 (Fig. 1), respectively. In addition, our C. angulata sequence obtained for a 444-nt fragment of the $\mathrm{mt}$ $16 \mathrm{~S}$ gene is identical to that of Taiwanese samples $(\mathrm{J}-\mathrm{H}$ Cheng, personal communication) although it differs from Japanese samples by three transitions (data not shown).

Another, more remote, possibility is that the source population for Crassostrea angulata was indeed Japanese, but that this genetic stock has been displaced during the past half milleninum. Remarkably, there may be a recent precedent for this scenario as the Kumamoto oyster, C. sikamea, has apparently become displaced/ extinct within the past 40 years in its home range in Kyushu and is now found only in North American culture operations (Banks et al. 1993, 1994). One of the contributing factors identified in the apparent extirpation of C. sikamea in Japan (Banks et al. 1994) has been the mass distribution of $C$. gigas seed, particularly from Miyagi populations, throughout Japan by oyster culturists (Ozaki and Fujio 1985). The process of homogenization or swamping by cultured oysters may be still in progress. Genetic distances (Nei's unbiased $D$ ) based on five polymorphic allozyme loci ranged from 0.045 to 0.064 among Hokkaido, Miyagi and Kyushu natural populations in 1979 (Fujio 1979). Less than a decade later, both northern (Hokkaido) and southern (Kyushu) populations were more similar ( $D$-values 0.011 to 0.029 for the same loci) to Miyagi (central Japan) seed source populations (Ozaki and Fujio 1985). Culture-related transfer may also account for the surprising absence of polymorphism in our C. gigas specimens, especially in the natural population samples from opposite ends of Japan (Kyushu, Hokkaido). It is possible that we en- countered the predominant Miyagi haplotype in our modest sample of five individuals each from the respective geographic ranges of the four historical Japanese stocks. A large scale population genetic survey of Japanese populations is required to address this issue.

The phylogenetic relationships of the Portuguese oyster Crassostrea angulata are unusually interesting because several independent lines of evidence including larval shell morphology, allozymes, breeding experiments and now mitochondrial gene sequences, strongly indicate that this oyster is of recent Asian origin. It may represent a case of undocumented anthropogenic introduction dating from the earliest days of circumglobal navigation. The mitochondrial data are the first to show the genetic distinctiveness of Portuguese oysters and present-day Japanese stocks of Pacific oysters. Ongoing genetic characterization of Pacific oysters throughout their Asian range promises to fully expose the phylogenetic relationships among Portuguese and Pacific oysters and to positively identify convincing Asian source populations for $C$. angulata.

Acknowledgements We thank M.J.S. Almeida for forwarding samples of $C$. angulata. M. Oishi and $\mathrm{H}$. Honma kindly helped us obtain Hokkaido samples of C. gigas, and C. Langdon provided Kyushu samples of the same species. Our thanks to S. Allen for supplying samples of Miyagi and Hiroshima C. gigas in addition to C. ariakensis. A. Robinson provided samples of $C$. sikamea, and A. Jeffs supplied samples of Ostrea chilensis. Our thanks to P. Boudry, and to Jin-Hua Cheng and Tzyy-Ing Chen, for forwarding unpublished results.

\section{References}

Ahmed M (1975) Speciation in living oysters. Adv mar Biol 13: 357-397

Banks MA, Hedgecock D, Waters C (1993) Discrimination between closely related Pacific oyster spp. (Crassostrea) via mitochondrial DNA sequences coding for large subunit rRNA. Molec mar Biol Biotechol 2: 129-136

Banks MA, McGoldrick DJ, Borgeson W, Hedgecock D (1994) Gametic incompatibility and genetic divergence of Pacific and Kumamoto oysters, Crassostrea gigas and C. sikamea. Mar Biol 121: $127-135$

Beckenbach AT (1994) Mitochondrial haplotype frequencies in oysters: neutral alternatives to selection models. In: Golding B (ed) Non-neutral evolution: theories and molecular data. Chapman and Hall, New York, pp 188-198

Boom JDG, Boulding EG, Beckenbach AT (1994) Mitochondrial DNA variation in introduced populations of Pacific oyster Crassostrea gigas in British Columbia. Can J Fish aquat Sciences 51: 1608-1614

Boore JL, Brown WM (1994) Complete DNA sequence of the mitochondrial genome of the black chiton, Katharina tunicata. Genetics 138: 423-443

Boudry P, Heurtebise S, Collet B, Cornette F, Gérard A (1998) Differentiation between populations of the Portuguese oyster, Crassostrea angulata (Lamarck) populations and the Pacific oyster, Crassostrea gigas (Thunberg), revealed by mtDNA RFLP analysis. J exp mar Biol Ecol (in press)

Brandiff B, Moy GW, Vacquier VD (1978) Isolation of sperm bindin from the oyster (Crassostrea gigas). Gamete Res 1: 89-99

Bremer K (1995) Branch support and tree stability. Cladistics 10: 295-304

Buroker NE, Hershberger WK, Chew KK (1979) Population genetics of the family Ostreidae. I. Intraspecific studies of 
Crassostrea gigas and Saccostrea commercialis. Mar Biol 54: 157-169

Carlton JT (1985) Transoceanic and interoceanic dispersal of coastal marine organisms: the biology of ballast water. Oceanogr mar Biol A Rev 23: 313-371

Carlton JT (1987) Mechanisms and patterns of transoceanic marine biological invasions in the Pacific Ocean. Bull mar Sci 41: 467499

Carlton JT (1989) Man's role in changing the face of the ocean: biological invasions and implications for conservation of nearshore environments. Conserv Biol 3: 265-273

Carlton JT, Geller JB (1993) Ecological roulette: the global transport of non-indigenous marine organisms. Science 261: 78-82

Carlton JT, Hodder J (1995) Biogeography and dispersal of coastal marine organisms: experimental studies on a replica of a 16thcentury sailing vessel. Mar Biol 121: 721-730

Clary DO, Wolstenholme DR (1985) The mitochondrial DNA molecule of Drosophila yakuba: nucleotide sequence, gene organization and genetic code. J molec Evolut 22: 252-271

Cohen AN, Carlton JT, Fountain MC (1995) Introduction, dispersal and potential impacts of the green crab Carcinus maenus in San Francisco Bay, California. Mar Biol 122: 225-237

Collins TM, Frazer K, Palmer AR, Vermeij GJ, Brown WM (1996) Evolutionary history of northern hemisphere Nucella (Gastropoda, Muricidae): molecular, morphological, ecological and paleontological evidence. Evolution 50: 2287-2304

Edwards C (1976) A study in erratic distribution: the occurrence of the medusa Gonionemus in relation to the distribution of oysters. Adv mar Biol 14: 251-284

Folmer O, Black M, Hoeh W, Lutz R, Vrijenhoek R (1994) DNA primers for amplification of mitochondrial cytochrome $c$ oxidase subunit I from diverse metazoan invertebrates. Molec mar Biol Biotechnol 3: 294-299

Fujio Y (1979) Enzyme polymorphism and population structure of the Pacific oyster (Crassostrea gigas). Tohoku J agric Res 30: $32-42$

Gaffney PM, Allen SK (1993) Hybridization among Crassostrea species: a review. Aquaculture, Amsterdam 116: 1-13

Geller J (1996) Molecular approaches to the study of marine biological invasions. In: Ferraris JD, Palumbi SR (eds) Molecular zoology: advances, strategies and protocols. Wiley-Liss, New York, pp 120-132

Gutíerrez M, Crespo JR, Pascual YE (1978) Ultraestructura de ovocitos y espermatozoides del ostión, Crassostrea angulata Lmk. de la costa sudátlantica de España. Investigación pesq 42: $167-178$

Hallegraeff GM, Bolch CJ (1992) Transport of diatom and dinoflagellate resting spores in ship's ballast water: implications for plankton biogeography and aquaculture. J Plankton Res 14: 1067-1084

Hedgecock D, Banks MA, McGoldrick DJ (1993) The status of the Kumamoto oyster Crassostrea sikamea (Amemiya, 1928) in U.S. commercial brood stocks. J Shellfish Res 12: 215-221

Hèral M, Deslous-Paoli JM (1991) Oyster culture in European countries. In: Menzel W (ed) Estuarine and marine bivalve mollusk culture. CRC Press, Boca Raton, Florida, pp 153-190

Imai T, Sakai S (1961) Study of breeding of Japanese oyster, Crassostrea gigas. Tohoku J agric Res 12: 25-165

Komaru A, Konishi K, Wada KT (1994) Ultrastructure of spermatozoa from induced triploid Pacific oyster, Crassostrea gigas. Aquaculture, Amsterdam 123: 217-222

Korringa P (1976) Farming the cupped oysters of the genus Crassostrea. Elsevier, Amsterdam

Lawrence DR (1995) Diagnosis of the genus Crassostrea (Bivalvia, Ostreidae). Malacologia 36: 185-202

Littlewood DTJ (1994) Molecular phylogenies of cupped oysters based on partial 28S rRNA gene sequences. Molec Phylogenetics Evolut 3: 221-229
Mathers NF, Wilkins NP, Walne PR (1974) Phosphoglucose isomerase and esterase phenotypes in Crassostrea angulata and C. gigas. Biochem Syst Ecol 2: 93-96

Mattiucci S, Villani F (1983) Studio elettroforetico dei sistemi geneenzima in ostriche classificate come Crassostrea gigas (Thunberg, 1793) e Crassostrea angulata (Lamarck, 1819) (Mollusca: Ostreidae). Parassitologia 25: 21-27

Menzel RW (1974) Portuguese and Japanese oysters are the same species. J Fish Res Bd Can 31: 453-456

Moré P, Moré M-T, Monnet M, Poisbeau J (1971) Electrophorèse en gel de polyacrylamide des protéines solubles de partie transparente du muscle adducteur de cinq espèces d'Ostreidae. Intérêt taxonomique. C r hebd Séane Acad Sci, Paris 273: 222 225

Numachi K (1962) Serological studies of species and races in oysters. Am Nat 96: 211-217

Ó Foighil D, Gaffney PM, Hilbish TJ (1995) Differences in mitochondrial 16S ribosomal gene sequences allow discrimination among American [Crassostrea virginica (Gmelin)] and Asian $[C$. gigas (Thunberg), C. ariakensis Wakiya] oyster species. J exp mar Biol Ecol 192: 211-220

Ozaki H, Fujio Y (1985) Genetic differentiation in geographical populations of the Pacific oyster (Crassostrea gigas) around Japan. Tohoku J agric Res 36: 49-61

Paine RT (1993) A salty and salutary perspective on global change. In: Kareiva PM, Kingsolver JG, Huey RB (eds) Biotic interactions and global change. Sinauer, Sunderland, Massachusetts, pp 347-355

Por FD (1989) The legacy of Tethys, an aquatic biogeography of the Levant. Kluwer Academic Publishers, Dordrecht

Quayle DB (1988) Pacific oyster culture in B.C. Can Bull Fish aquat Sciences 218: 1-241

Ranson G (1948) Prodissoconques et classification des ostréides vivants. Bull Mus $r$ Hist nat Belg 24: 1-12

Ranson G (1960) Les prodissoconques (coquilles larvaires) des ostréides vivants. Bull Inst océanogr Monaco 1: 1-41

Ranson G (1967) Les espèces d'huîtres vivant actuellement dans la monde, définies par leurs coquilles larvaires ou prodissoconques. Etude des collections de quelques-uns des grands musées d'histoire naturelle. Revue Trav Inst (Scient tech) Pêch marit 31: $127-274$

Reeb CA, Avise JC (1990) A genetic discontinuity in a continuously distributed species: mitochondrial DNA in the American oyster, Crassostrea virginica. Genetics 124: 397-406

Reid DG, Rumbank E, Thomas RH (1996) DNA morphology and fossils: phylogeny and evolutionary rates of the gastropod genus Littorina. Phil Trans R Soc (Ser B) 351: 877-895

Robba E (1987) The final occlusion of Tethys: its bearing on Mediterranean benthic molluscs. In: McKenzie KG (ed) Shallow Tethys 2. Balkema, Rotterdam, pp 405-426

Sorenson MD (1996) TreeRot. University of Michigan, Ann Arbor Sousa M, Oliveira E (1994) An ultrastructural study of Crassostrea angulata (Mollusca, Bivalvia) spermatogenesis. Mar Biol 120: $545-551$

Stenzel HB (1971) Oysters. In: Moore KC (ed) Treatise on invertebrate paleontology. Part N. Vol. 3. Mollusca 6. Boulder Colorado. Geological Society of America Inc, Boulder, Colorado and the University of Kansas, Lawrence, pp N935-N1224

Swofford DL (1993) PAUP: phylogenetic analysis using parsimony. Version 3.1. Illinois Natural History Survey, Champaign

Thiriot-Quiévreux C (1984) Analyse comparée des caryotypes d'Ostreidae (Bivalvia). Cah Biol mar 25: 407-418

Walne PR, Helm MM (1979) Introduction of Crassostrea gigas into the United Kingdom. In: Mann R (ed) Exotic species in mariculture. MIT Press, Cambridge, Massachusetts, pp 83-105 